\title{
薬 酒について
}

堀口貞 次 郎/盖命酒製造(株)

\section{中国における薬酒の歴史}

薬酒の歴史は非常に古く, 酒それ自身が薬であった時 代もあったわけです。しかし，酒が薬酒として体形化さ れたのは，西洋では扮拈よそ 1800 年前口ーマ時代の名 医ガレヌスがブドウ酒に薬草を浸して作ったといらガレ スス製剤が初めであるといわれて招ります。一般我々 がいら薬酒とは, 東洋のものをさして扣り,この薬酒を 知るためには当然, 東洋医学である漢方から検討しなけ ればなりません。

伝説によれば，今から扮怙上そ 4300 年前神農氏が百 草をなめて薬にしたのが漢方の初めだといわれていま す。その頃の中国は神代時代に当り，この神農・黄帝時 代に農耕が始まったといわれますから，当然果実を原料 としたような自然発生的な酒は当時あったものと想像さ れます。そして领用の目的から穀物で酒が造られたのは それより少し後の禹王の頃, すなわち夏の時代といわれ ます。また,一説によりますと黄帝時代という説もあり， いずれにしても中国の有史前後であることには変りあり ません。一方薬の方も段々発達して最初粉末であったも のが怙怙よそ 3300 年前には煎じ薬である煎剤の方法が 用いられ, 漢方の古典とされている神農本草経 (BC 300 年頃で現在ない。その後 DC 500 年頃陶弘景によって集 注され，現在のものはこれに当る）が作られた頃には薬 を酒に浸して飲むとか，酒で割って飲むといら方法が用 いられてきたわけです。ですから，ガレススの薬酒より 以前には，すでに中国に薬酒があったことになります。 古代中国が地域的に分裂していたとはいえ，国家形態 をとるようになってからは病気を治すという考觉から不 老長寿を願らといら, 人間の欲望によって薬の範囲も広 くなり, それ故, 漢方が急速に発達したわけです。そし
て百薬の長といわれる酒の発達と共に両者がごく自然に 融合して薬酒が造られたものと思います。

漢方薬が体形化されてからの内服方法には湯, 醴, 丸, 散, 丹の五つの形態がありますが，この中の醴は薬酒を 意味しています。その当時の不老長寿と考兄られる強 壮・強精の生薬（天然界に存在し，薬用に供すことので きる薬物）はなんでも薬酒にする傾向が見られたようで す。1596 年に出された本草書, すなわち本草綱目（李時 珍）の中には 69 種の薬酒が載って招り,この薬酒は大 部分が不老長寿を目的とするもので，その内容も単味生 薬からできているのが特辩です。また，その製造方法も 単に生薬を酒に浸したものと, 生薬またはその煎じ汁を 麭とで酒にかもして造る二通りがあり，前者を「醴」と いい, 後者を「酒」と説明しています。これを利用目的の 面からみますと，治療を目的とした薬酒には「酒」の製 法が適さないのか, あまり用いていません。しかし, 強 壮・強精を目的とした不老長寿の薬酒には生薬の性質に よって, その方法が決まり, 植物性生薬は一般に「酒」 に多く, 動物性生薬の場合には「醴」の方法が多く用い られています。こうしてできた薬酒は本草綱目の中では 次のように説明しています。「少量领めば血を和し, 気 をめぐらし，神を壮にして寒を防ぎ，うれいを消し興を やる」しかし「痛领すれば神をそこない，つい血をやし 胃を損じ，精を失い疾を生ずる」と説明しています。す なわち，少量では血液の循環をよくし，元気をつけて体 を大夫にするが，飲みすぎるとかえって体に悪いことを 説明して扣ります。

\section{我国における薬酒の歴史}

さて, 我国に拈ける薬酒の歴史は中国に比較して日が 浅く，中国に漢方があったと同様日本にも我国独自の民 
間薬があり，当然薬酒に打いても中国に劣らないものが あったようです。記録の上では中国との文化交流によっ て伝わったものが多く, 平安時代（811 年）宮中で用い られた屠蘇酒が初めだといわれております。この屠蘇酒 は況儀に用いられる薬酒で, 後漢 (366 年) の名医華陀 によるもので，この風習は中国からきたものです。そし て, そもそもの由来は年中無病を念願するために, 年頭 に扮いて邪気を払い除くとい5目的にあったわけですか ら, その原料も白求, 桂皮, 防風, 山椒, 桔梗, 大黄, 乾姜, 烏頭とい5よ5な香りの高い芳香性の生薬が多く 用いられています。この風習は後に，宮中から庶民に広 まり，と同時に中国でみられた不老長寿の薬酒も当然広 まったわけです。このように人間が不老長寿を念願する 点では, いずこも同じであったわけです。こうして広ま った不老長寿の薬酒, すなわち強壮・強精薬は本草綱目 にみられるような人参酒, 五加皮酒, 仙霊脾酒, 鹿茸酒, 蝮蛇酒, 地黄酒, 虎骨酒, 枸杷酒, 竜眠酒など代表的な ものをあげることができます。これらは本草綱目に載っ ているような単味生薬あるいは簡単な処方から一歩進ん だ配合に変っており，もちろん，時代の差は当然ありま すが，その処方も日本でとい5よりも中国で改良された ものが入ってきたものと考光られます。しかし，これら は漢方の古典を基本として作ったことには変りありませ ん。

こうして, 我国で本格的に発達した薬酒は中国で長い こと経験的に改善されてきたものですから，処方も単味 のものが少なく、配合的な処方になっております。また， 製造の方も酒の発達とともに薬草と粼とで酒にするとい 万酒の方法から単に酒に浸すという「醴」の方向に変って きたわけです。この両者はいずれも薬酒といら点では同 じですが，生薬の性状およびその効果から製法が变り， 問題はその薬酒の効果において差異があるかどうかとい らことです。本草綱目では差異があることを認めており， 経験医学として考えられてきた漢方の深さを思い知るこ とができます。

このように, 我国に打ける薬酒の発達はある程度, 体形 化された処方が中国から伝承されてきたため，治療を目 的とする薬酒の期間がごく短く, 強壮・強精を目的とし たものから発達したようにも考劣られます。この薬酒の 発達す不老長寿を目的とするものであれば当然強壮・強 精作用を示す生薬が主体をなしていることには変りあり ません。問題は，この作用を更に側面から助けるような 生薬が必要になってくるわけで, 漢方薬だけが持ってい る独特の相剩効果から体全体に働く処方に変ってきたわ けです。ですから，胃腸も，肝蔵も，腎蔵にも……すべ てが正常で調和がとれたものでなければ意味がないわけ
です。るちろん，この配合も経験的からきたもので, 中 はり, 主体をなす生薬はその当時のものと変りなく, 現 在知られている薬酒の中で比較的多く用いられている生 薬を紹介しますと, 人参 (強壮・強精), 地黄 (滋養・強 壮), 鹿茸 (強壮・強精), 白求 (健等 - 腎機能障害), 五 味子 (滋養・強壮), 当帰 (産前・産後), 伏荅 (利尿 淋疾), 甘草 (解毒), 反鼻 (強精・新陳体謝), 枸 杷子 (強壮), 蛤蚧 (強精), 杜仲 (強壮 - 強精・鎮痛), 黄著 (心藏病・血管強壮), 肉蓯蓉 (強壮・強精), 淫羊蒦 (強 壮・強精) などの生薬がみられます。このように, 生薬 の中には動物性生薬である鹿茸, 反鼻, 蛤蚧などいろい ろありますが, 比較的多く用いられる強壮・強精の処方 の中では, このような動物性生薬が一つ位配合されてい るのが特徴かと思われます。こうしてできた桼酒の中に は神秘的とか, 迷信的とか感じる薬酒が多々ありますが, さすがは経験医学で作り出された漢方だけあって, 近代 科学の前に迷信が迷信でない学術的説明がなされてきて います。

\section{薬酒に使われる生薬}

薬酒の中には変ったものもあり, 昔の伝説の中に山䀟 退治に出掛けて反対に「シビレ酒」を飲まされて降参し たという豪傑の話もあります。これに用いられた生薬 は, いずれも猛毒な薬草で鳥頭, ダッラ葉, 釣吻, 透山 根（?）などからできたもので，今考劣れば神経麻痺を 起すようなアルカロイド成分（アコニチン，ヒヨスチア ミン）を含んでおり，納得ができましょう。また，ヤモ リの黒焼き（蛤蚧）で作った薬酒を恋しい人に飲ませる といら昔ながらの「ホレ薬」の話しがあります。これも 動物実験の結果, 雌動物に与えることによって性殖器を 非常に発達させ，子宮や卵巣を去勢させた動物です性木 ルモンを再現させることができるというのですから，こ の強精作用の強烈さからみて, ほれ薬の話しも決してい いかげんな作り話しでないといらことが解りましょう。 このょうに薬酒はいろいろの面から活用されております が, やはり, 強壮・強精を考号てのものが比較的多く, これはこの種の処方が薬酒にするのに一番適しているか らで，各々の処方内容や効果の面から製刘の形が決まる わけだが, この点, 強壮・強精剤は薬酒という方法を用 いることによって，吸収をよくし，速効性を高め，しか る领みやすいということから継続的に毎日领用できると いう特徴を持っています。それ故，薬酒にする方法が適 しているものと思います。

薬酒には生薬の利用面から二通りに分けることができ ます。つまり本草綱目にあるような薬酒，すなわち単味 生薬あるいは数種混合したものと, 漢方処方に準じて全 
体から考兄てみてみたものに分類できます。この場合目 的は同じであって子効果の程度は当然異なるわけで, 例 えば, 鹿茸が強精剤としてよいということは経験的にも 知られて物り, また, 科学的にも男女両性ホルモンに似 た作用があると発表され，内容成分もパントコリンを抽 出し，その解明に力を入れているわけです。この鹿咠を 散剂や煎剂にせず酒に浸して用いると效果を更に高める ことができ, 本草綱目にある鹿茸酒の上らに山薬(ヤ、 ノイモ）を加党ることによってより巾の広い効果を期待 することがでさます。そして, 現在ではこの鹿草酒の中 に人参を加党ることによって，钐果を 3 倍にも 4 倍 そもすることが経験的にも動物実験でも解明できたので すから，漢方薬の相剩効果は口ではいい表わせない,つ まり，科学分析ではい党ない作用を持っていることを理 解できると思います。

ただ，たん生薬の面から薬酒をみすすと単味あるい は数種の生薬から強壮作用とい5複雑な效果を期待でき るかどらか疑間に思われますが中国で有名な強精酒（二 蛇酒，三蛇酒）を飲んだ先輩の話では，とても我慢でき なかったとい5位いですから，いちがいに単純な配合で も効果がないといらわけにも参りません。しかし，㭗の

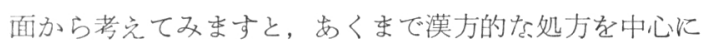
考光たものの方が体全体からみてよく調和されて扣り, その効果にも無理がないから安心です。

\section{薬酒の目的}

また, 薬酒の领用目的ですが, 一般に強壮の効果を期 待して飲まれる方が多い上うで, その目的も虚弱な体を 芯から丈夫にしようとする人, 強精剂として愛领する
人, 中には今夜という速急な効果を期待する人なとさ忘 ざまだと思います。しかし，強壮作用は前にも説明し京 したように体全体から考光てのものでなければ意味が歺 りません。局所的に作用する薬物も少なくありま世んぶ 長続きしませんし，その場は上くても体には上くありま せん。ですから強壮・強精を目的とする薬酒には相剩効 果を充分発揮することのできる処方にし, 巾の広、薬酒 であることが薬酒としての必要条件でもあるわけです。 薬酒本来のあり方は一時的な興奮剂であってはならない と思いますし，また，強精効果は飲用することによって 体を芯から丈夫にし，これに伴って表われてくる效果で なければなりなせん。1回や 2 回の服用によって効果の 出るようなものは必らず副作用を伴い薬酒としては満足 のできるものではないわけです。やはり, 漢方処方に準 じたもので経験的にも科学的にも安心のできるもので, たと光少量でめっても継続的に長い期間用いることが薬 酒としての本来の姿ではないでしょらか。そして，先の 効果は綜合効果となって表われてくるため, 少量でる継 続することによって大きな効果となって表われ，この点 が薬酒を強壮剤としてみた必要なことでもあるわけで 于。

薬酒の流れも初めは治療的な考克に立っていたのです が次第に尒防的な面に変り，そして近年では第三次医学 を代表するょり健康でありたいという健康增進, 体力向 上の面に変って扣り, 今後增及要求されて行く分野でも あると思い未す。そして薬酒本来のめり方は, これに上 って健康を保ち, 幸福な生活をして頂くことに出り, 私 共薬酒の製造にたずさわっている者の常偲願している ところでああるわけです。

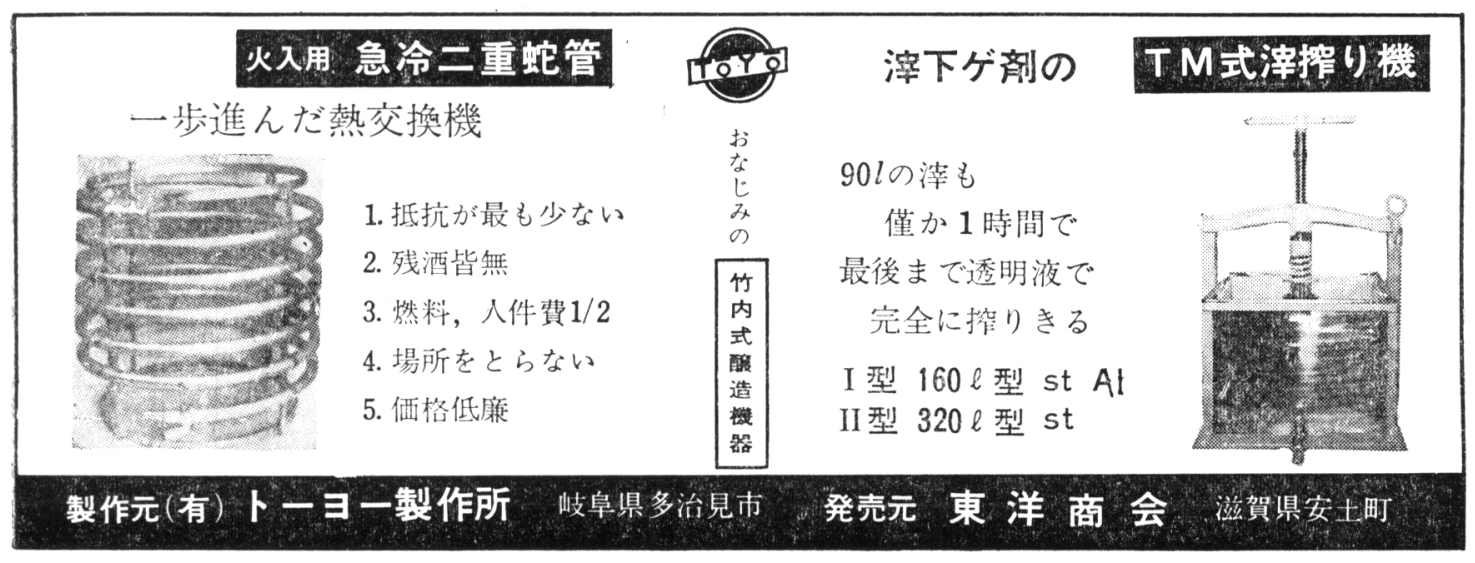

